\title{
Rancangan Bangun Alat Pakan Otomatis untuk Ikan Cupang Menggunakan Logika Fuzzy
}

\author{
Tata Sutabri $^{1 \text { ()), Tri Octavianto }}{ }^{2)}$, Yohanes Bowo Widodo ${ }^{3)}$ \\ ${ }^{12)}$ Fakultas Teknologi Informasi, Universitas Respati Indonesia \\ ${ }^{3)}$ Program Studi Teknik Informatika, Universitas Mohammad Husni Thamrin \\ ${ }^{*}$ Correspondence Author: tata.sutabri@gmail.com , Jakarta, Indonesia
}

DOI: https://doi.org/10.37012/jtik.v7i2.643

\begin{abstract}
Abstrak
Pada saat ini teknologi dan sistem informasi mengalami perkembangan yang sangat pesat. Seiring dengan perkembangan teknologi, manusia semakin dituntut kreatif untuk membuat peralatan yang memanfaatkan teknologi untuk meringankan kehidupannya. Internet Of Things adalah suatu konsep atau program dimana sebuah objek memiliki kemampuan untuk mentransmisikan atau mengirimkan data melalui jaringan tanpa menggunakan bantuan perangkat komputer dan manusia. Internet Of Things atau sering disebut dengan IoT saat ini mengalami banyak perkembangan. Sekarang ini ikan cupang sangat banyak dibudidayakan di masyarakat, tetapi banyak dari peternak atau pemelihara ikan cupang mengalami kesulitan pada saat memberi makan, karena ikan cupang adalah salah satu ikan yang jika diternak atau dipelihara tidak bisa ditempatkan dalam satu wadah yang sama. Sebab naluri bertarung ikan cupang yang cukup tinggi membuat ikan cupang harus dipisahkan satu sama lain. Hal ini membuat para peternak ikan cupang atau pemelihara membutuhkan waktu yang sangat lama untuk memberi makan, karena harus diberi makan satu per satu.

Dengan menggunakan algoritma berbasis logika $f u z z y$, akan dibuat program untuk memberi pakan ikan cupang otomatis. Penggunaan logika fuzzy membuat prorogram jauh lebih terstruktur dan terencana sehingga mampu memodelkan fungsi nonlinier yang kompleks dimana alat tersebut dapat memberi makan ikan cupang dengan pakan kutu air secara otomatis dan dapat dikontrol melalui aplikasi Blynk di smartphone. Alat ini dirancang menggunakan NodeMCU ESP8266 ditambah dengan motor Servo sebagai output dalam pemberian makan ikan cupang.
\end{abstract}

Kata kunci: NodeMCU ESP8266, Blynk, Logika Fuzzy, Ikan Cupang

\begin{abstract}
At this time technology and information systems are experiencing very rapid development. Along with the development of technology, humans are increasingly required to be creative to make equipment that utilizes technology to ease their lives. Internet of Things is a concept or program where an object has the ability to transmit or transmit data over a network without using the help of computer and human devices. The Internet of Things or often referred to as IoT is currently experiencing many developments. Currently, betta fish are very widely cultivated in the community, but many of the breeders or keepers of betta fish have difficulty when feeding, because betta fish is one of the fish that if bred or cared for cannot be placed in the same container. Because the fighting instinct of betta fish is high enough to make betta fish must be separated from each other. This makes betta fish breeders or keepers take a very long time to feed, because they must be fed one by one. By using an algorithm based on fuzzy logic, a program will be made to feed betta fish automatically. The use of fuzzy logic makes the program much more structured and planned so that it is able to model complex nonlinear functions where the tool can feed betta fish with water fleas feed automatically and can be controlled via the Blynk application on a smartphone. This tool is designed using NodeMCU ESP8266 coupled with a Servo motor as an output in feeding betta fish.
\end{abstract}

Keywords: NodeMCU ESP8266, Blynk, Fuzzy Logic, Betta Fish 


\section{PENDAHULUAN}

Secara singkat Internet of Things adalah teknologi di mana benda-benda di sekitar kita dapat berkomunikasi antara satu sama lain melalui sebuah jaringan Internet. Jadi Internet of Things (IoT) adalah sebuah konsep dimana suatu objek memiliki kemampuan untuk mentransfer data melalui jaringan internet. (Widodo, Ichsan, \& Sutabri, 2020)

Sekarang ini ikan cupang sangat banyak dibudidayakan di masyarakat, tetapi banyak dari peternak atau pemelihara ikan cupang yang mengalami kesulitan pada saat memberi makan, dikarenakan ikan cupang adalah salah satu ikan yang jika diternak atau dipelihara tidak bisa ditempatkan dalam satu wadah yang sama karena naluri bertarung yang tinggi. Hal tersebut membuat ikan cupang harus dipisahkan satu sama lain, sehingga membuat para peternak ikan cupang atau pemelihara membutuhkan waktu yang sangat lama untuk memberi makan ikan cupang, karena harus diberi makan satu per satu. Jika ikan cupang yang dimiliki mencapai puluhan bahkan ratusan ekor, maka akan sangat memakan waktu.

Alat yang akan dikembangkan hanya dapat memberi makan sekitar 3 ekor ikan cupang saja, namun di masa yang akan datang dapat dikembangkan lagi. Terlebih lagi ikan cupang paling efektif jika diberi pakan alami. Pakan buatan (organik) sangat tidak disarankan untuk pakan ikan cupang, karena akan menghambat pertumbuhan dan mutasi warna pada ikan cupang. Pakan alami terbaik untuk ikan cupang yaitu kutu air. Kutu air memiliki kandungan protein yang sangat tinggi untuk ikan cupang, yang dapat memicu pertumbuhan ikan cupang mulai dari ukuran, warna, dan menjaga kesehatan mental ikan cupang. Ikan cupang juga harus diberi makan 3 kali sehari dengan kutu air.

Pada penelitian ini akan dikembangkan sebuah alat yang dapat memberi makan ikan cupang dengan pakan kutu air secara otomatis dan dapat dikontrol melalui aplikasi Blynk di smartphone. Penggunaan algoritma berbasis logika fuzzy akan membuat program pakan ikan cupang otomatis akan jauh lebih terstruktur dan terencana sehingga mampu memodelkan fungsi nonlinier yang kompleks.

Penelitian sejenis yang telah dilakukan yaitu penelitian yang dilakukan oleh Feri Andriawan (2018) Mahasiswa dari Universitas Islam Blitar yaitu penjadwal pakan ikan koi otomatis pada kolam menggunakan RTC DS3231. Pada penelitian tersebut terdapat perancangan alat pakan otomatis untuk ikan koi dengan ukuran kolam 2,5m x 1,5m. Komponen alat pakan otomatis untuk ikan koi tersebut yaitu Arduino Uno, sensor utrasonik HC-SR04, RTC DS3231, motor servo, dan buzzer. Pemberian pakan dilakukan pada jam 08.00, 11.00, dan 14.00 dengan populasi ikan minimal 15 ekor maksimal 100 ekor. Pakan menggunakan pelet berbentuk kecil. Pembuatan alat penjadwalan pakan ikan secara otomatis 
menggunakan mikrokontroler Arduino Uno. Arduino Uno merupakan pengendali mikro single-board yang bersifat open source yang modul mikrokontrolernya menggunakan Atmega 328.

Penelitian lain yang sejenis yang sudah terbit di Jurnal Internasional "of South West Jiaotong University" berjudul "Tankmate Design For Settings Filter, Temperature, And Light On Aquascape". Hasil penelitian ini adalah perangkat IoT yang mampu memonitor dan mengontrol suhu, cahaya dan penyaring air. Kontrol filter, suhu dan cahaya dapat dilakukan secara otomatis, atau dimonitor dan dikendalikan dari jarak jauh. Piranti yang digunakan adalah Arduino-compatible board berbasis mikrokontroler ATMega328/P yang terhubung ke web services dan web portal untuk monitoring dan mengatur aquascape. (Sutabri, Widodo, Sibuea, Rajiani, \& Hasan, 2019)

Studi diatas digunakan sebagai pembanding antara penelitian yang sudah dilakukan sebelumya dengan yang akan dilakukan. Terdapat perbedaan antara penelitian pakan ikan koi otomatis dan pakan ikan cupang otomatis dibuat, contohnya dari jenis mikrokontroler, disini digunakan NodeMCU ESP8266. Digunakan juga aplikasi blynk sebagai pengontrol keluarnya pakan secara terpisah. Fungsi motor servo yang digunakan juga berbeda, motor servo digunakan untuk pengarah pakan otomatis tersebut, dan tidak terdapat sensor pada penelitian ini.

\section{METODE}

Pendekatan penelitian yang dipakai adalah metode Research and development (R\&D). Metode ini merupakan penelitian yang hasilnya digunakan untuk membantu pelaksanaan pekerjaan. Dengan dibantu produk yang telah dihasilkan maka akan semakin produktif, efektif, dan efisien. Metode penelitian (R\&D) juga merupakan suatu proses atau langkah-langkah untuk mengembangkan suatu produk baru atau menyempurnakan produk yang telah ada, yang dapat dipertanggungjawabkan (Nusa Putra, 2017)

Langkah langkah dalam pendekatan penelitian metode (R\&D) :

1. Menentukan potensi dan masalah

Menentukan potensi dan masalah, menurut Sugiyono (2016) disampaikan bahwa potensi adalah segala sesuatu yang jika didayagunakan akan memiliki nilai tambah. Dalam penelitian Research \& Development harus dimulai dengan adanya potensi.

2. Mengumpulkan data 
Mengumpulkan data, merupakan proses untuk mendapatkan informasi-informasi tertentu, digunakan sebagai landasan dalam mengembangkan suatu alat tertentu. (Sugiyono, 2016)

3. Mendesain alat

Desain alat harus diwujudkan dalam bentuk gambar atau bagan. Dengan mewujudkan desain dalam bentuk gambar atau bagan, akan mempermudah peneliti dalam mewujudkan alat yang sesuai dengan rencana dan dapat bermanfaat. (Sugiyono, 2016)

4. Memvalidasi desain alat

Memvalidasi desain merupakan proses kegiatan untuk menilai apakah alat yang diciptakan dapat efektif ketika diterapkan di lapangan. (Sugiyono, 2016)

5. Revisi desain alat

Sugiyono (2016) menyampaikan bahwa setelah desain alat, divalidasi melalui diskusi dengan pakar dan para ahli lainnya, maka akan diketahui kelemahannya. Perbaikan desain adalah proses yang dilakukan untuk memperbaiki kelemahan dari desain alat yang ditemukan dari proses validasi.

6. Uji coba alat

Uji coba alat, tujuannya yaitu untuk mendapatkan informasi apakah alat dikembangkan efektif dalam penerapannya. Pengujian sendiri dapat dilakukan dengan cara eksperimen yaitu membandingkan antara efektifitas alat terbaru dengan terdahulu.

Tempat penelitian dilaksanakan di King Rosetail, J1. Sepakat III No.25, RT.8/RW.1, Cilangkap, Kec. Cipayung, Kota Jakarta Timur, Daerah Khusus Ibukota Jakarta. Peternakan ikan cupang ini cukup dikenal dan terdapat beragam jenis ikan cupang. Alat pakan otomatis untuk ikan cupang yang diciptakan ini dapat digunakan oleh peternak dan sekaligus memberi edukasi tentang perkembangan teknologi terutama dalam bidang IoT.

Dalam bahasa inggris, fuzzy mempunyai arti kabur atau tidak jelas. Jadi logika fuzzy adalah logika yang kabur atau mengandung unsur ketidakpastian. Pada logika biasa, yaitu logika tegas, hanya dikenal dua nilai, salah atau benar, 0 atau 1. Sedangkan logika fuzzy mengenal nilai antara benar dan salah. Kebenaran dalam logika fuzzy dapat dinyatakan dalam derajat kebenaran yang nilainya antara 0 sampai 1. Misalnya dalam kehidupan seharihari, dewasa didefinisikan dengan berusia 17 tahun ke atas. Jika menggunakan logika tegas, seseorang yang berusia 17 tahun kurang 1 hari akan didefinisikan sebagai tidak dewasa. Namun dalam logika fuzzy, orang tersebut dapat dinyatakan dengan hampir dewasa. 


\section{HASIL DAN PEMBAHASAN}

Pada penelitian ini, digunakan aquarium ukuran dengan panjang dan lebar $30 \mathrm{~cm} \mathrm{x}$ $10 \mathrm{~cm}$. Aquarium dibagi menjadi masing masing panjang $10 \mathrm{~cm}$ menggunakan 2 buah sekat, agar bisa difungsikan untuk menampung 3 ekor ikan cupang.

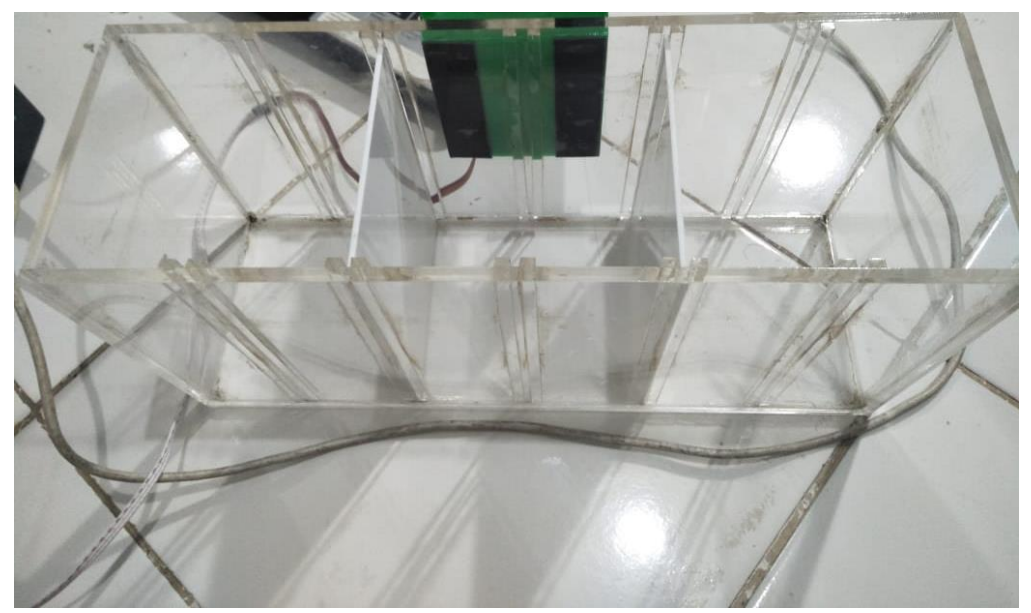

Gambar 1. Aquarium yang digunakan

Komponen perangkat keras yang digunakan adalah sebagaimana tercantum di tabel 1 berikut ini:

Tabel 1. Komponen Perangkat Keras yang Digunakan

\begin{tabular}{lll}
\hline No & Komponen & Fungsi \\
\hline 1 & NodeMCU ESP8266 & $\begin{array}{l}\text { Sebagai mikrokontroller yang dapat } \\
\text { terhubung ke Internet }\end{array}$ \\
\hline 2 & Regulator LM2596 & $\begin{array}{l}\text { Menjaga tegangan listrik agar tetap } \\
\text { stabil }\end{array}$ \\
\hline 3 & Adaptor & $\begin{array}{l}\text { Menurunkan tegangan sesuai jenis } \\
\text { adaptor tersebut }\end{array}$ \\
\hline 4 & Relay & $\begin{array}{l}\text { Komponen listrik yang berfungsi } \\
\text { mengendalikan dan mengalirkan listrik }\end{array}$ \\
\hline 5 & Real Time Clock (RTC) & $\begin{array}{l}\text { Modul pewaktu digital yang dapat } \\
\text { dikendalikan }\end{array}$ \\
\hline 6 & Motor Direct Current (DC) & Motor DC difungsikan sebagai generator \\
\hline 7 & Motor Servo & $\begin{array}{l}\text { Sebagai alat pakan otomatis, nantinya } \\
\text { servo akan dapat berputar sesuai arahan } \\
\text { pengguna }\end{array}$ \\
\hline 8 & Kabel Jumper & $\begin{array}{l}\text { Sebagai kabel penghubung antar } \\
\text { komponen pada Printed Circuit } \\
\text { Board (PCB) }\end{array}$ \\
\hline 9 & Printed Circuit Board (PCB) & $\begin{array}{l}\text { Sebagai tempat merangkai komponen } \\
\text { dengan melakukan penyolderan }\end{array}$ \\
\hline 10 & Aquarium & Sebagai wadah 3 ekor ikan cupang \\
\hline 11 & Box & $\begin{array}{l}\text { Sebagai tempat penyimpanan komponen } \\
\text { alat }\end{array}$ \\
\hline
\end{tabular}


Adapun skematik keseluruhan rangkaian dalam perancangan alat ini sebagai berikut:

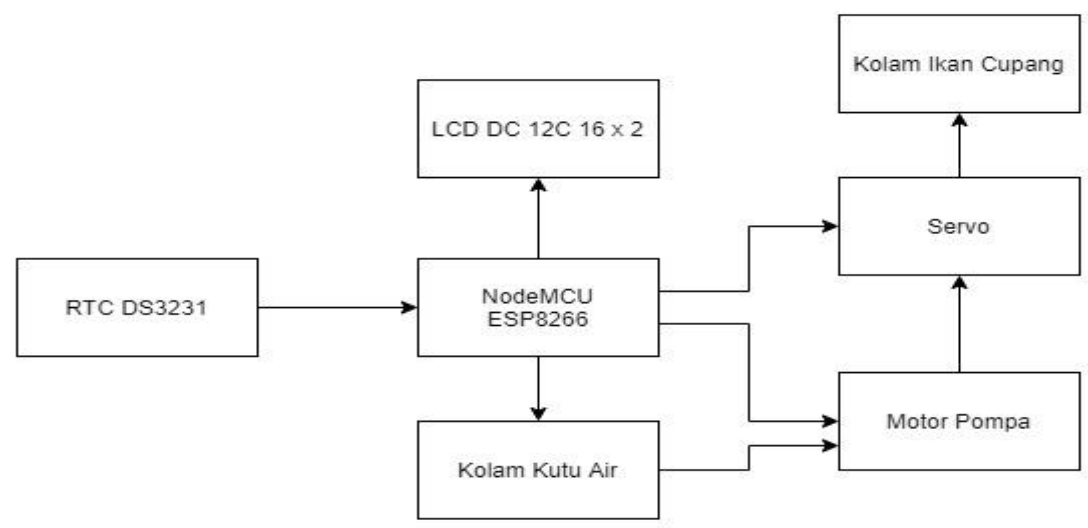

Gambar 2. Skema Keseluruhan rangkaian

Komponen perangkat lunak yang digunakan adalah sebagaimana tercantum di tabel 2 berikut ini:

Tabel 2. Perangkat Lunak yang Digunakan

\begin{tabular}{c|c|l}
\hline No & Komponen & \multicolumn{1}{c}{ Fungsi } \\
\hline 1. & Arduino IDE & $\begin{array}{l}\text { Software yang digunakan untuk } \\
\text { memprogram alat pakan otomatis. }\end{array}$ \\
\hline 2. & Blynk & $\begin{array}{l}\text { Sebagai platform loT yang berfungsi } \\
\text { untuk mengendalikan pakan otomatis }\end{array}$ \\
\hline
\end{tabular}

Arduino IDE (Integrated Development Environment) adalah sebuah perangkat lunak yang digunakan untuk mengembangkan pemrograman aplikasi mikrokontroler mulai dari menuliskan source program, kompilasi, upload hasil kompilasi dan uji coba secara terminal serial. Perangkat lunak ini berupa algoritma kerja dari suatu alat yang berbentuk listing program yang ditanamkan ke dalam mikrokontroler Blynk.

Blynk adalah platform untuk aplikasi OS Mobile (iOS dan Android) yang bertujuan untuk kendali modul Arduino, NodeMCU esp8266, WEMOS D1, dan modul sejenisnya melalui Internet. Blynk diciptakan dengan tujuan untuk control dan monitoring hardware secara jarak jauh menggunakan komunikasi data internet dari kartu SIM mobile. 
Pemodelan sistem yang digunakan untuk membuat alat pakan otomatis ini menggunakan Flow Of Document (FOD), Flow Of Document merupakan bagan alir yang menggambarkan arus pekerjaan secara keseluran dari sistem yang dianalisis.

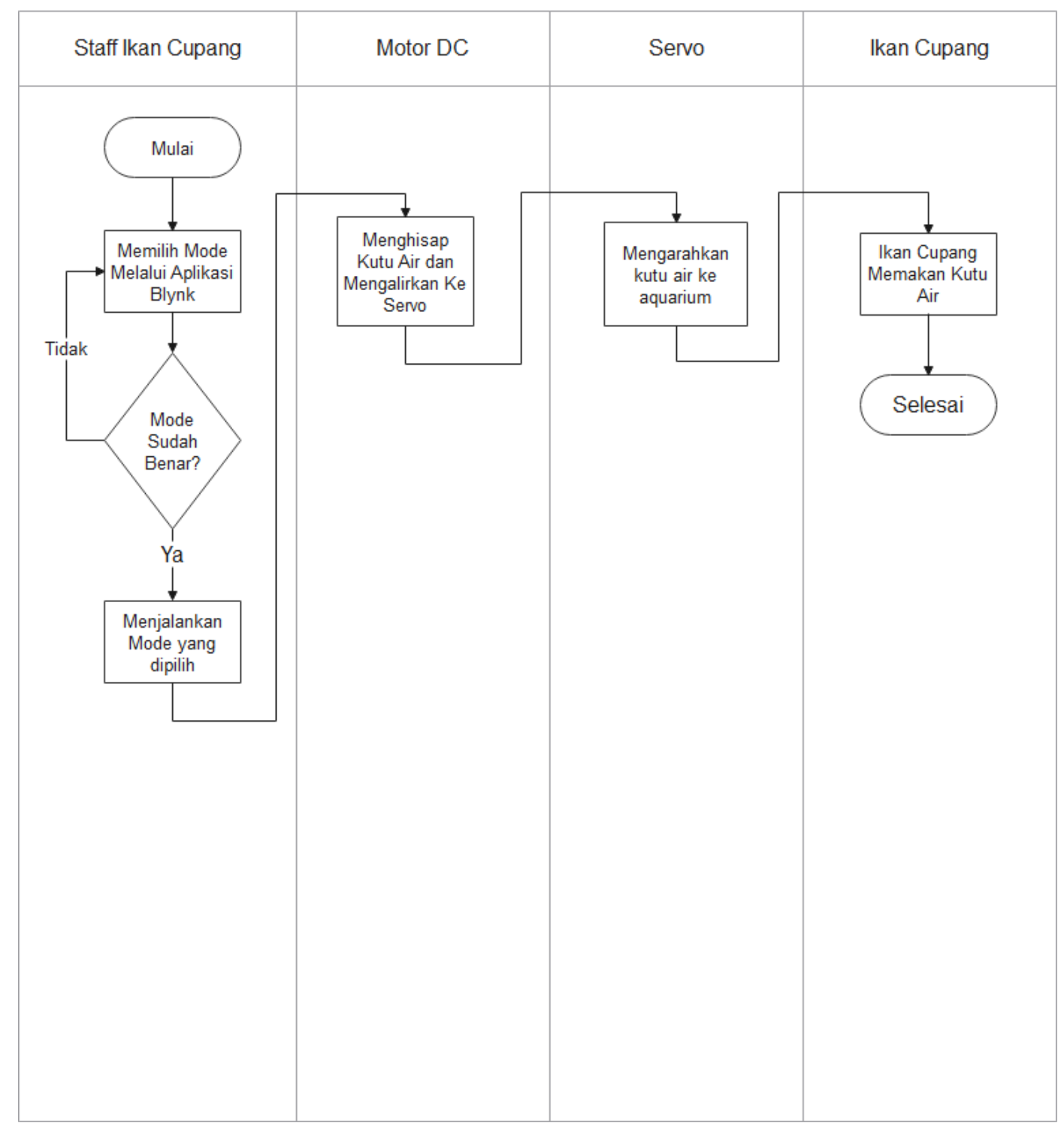

Gambar 3. Flow Of Document pakan otomatis

Berdasarkan pada gambar 3 dapat diuraikan alur proses dari perangkat sebagai berikut:

1. Langkah pertama ditandai dengan simbol terminal "Mulai" yang berfungsi untuk mengawali sebuah program.

2. Memilih mode manual atau otomatis dalam aplikasi blynk, mode otomatis dapat memberi pakan secara otomatis dalam 3x sehari di jam 7 pagi, jam 1 siang, dan jam 4 sore. Namun jika mode manual, alat pakan ikan cupang tersebut hanya dapat bekerja jika user mengklik tombol ON pada menu di aplikasi blynk. 
3. Langkah ketiga terdapat simbol keputusan, apakah mode sudah sesuai dengan yang di inginkan, jika tidak, akan kembali memilih mode, dan jika ya, mode yang dipilih akan dijalankan.

4. Di langkah keempat aplikasi blynk akan menjalankan mode yang di inginkan.

5. Di langkah kelima, jika mode sudah berjalan, maka motor DC akan secara otomatis menghisap kutu air kemudian akan mengalirkannya ke servo melalui selang.

6. Langkah keenam servo akan bergerak 3 arah dari mulai $45^{\circ}, 90^{\circ}, 135^{\circ}$ untuk memberi makan ikan cupang melalui selang.

7. Langkah ketujuh ikan cupang akan memakan kutu air tersebut.

8. Langkah kedelapan semua proses berlanjut yang ditandai dengan terminal "Selesai" yang berfungsi menandai berhasilnya program dijalankan.

Perakitan perangkat keras pada gambar 4 terdiri dari NodeMCU, Relay, Regulator, Kabel Jumper, Liquid Crystal Display (LCD), Real Time Clock (RTC), motor pompa, motor servo. Relay digunakan untuk dapat menggerakkan kontak saklar sehingga dengan arus listrik yang kecil dapat menghantarkan listrik yang bertegangan lebih tinggi yang nanti akan dikirimkan ke NodeMCU ESP8266 sebagai mikrokontroller dan akan diteruskan oleh koneksi wifi lalu sinyal diterima oleh aplikasi Blynk dan aplikasi Blynk dapat membuat perintah memberi makan otomatis ataupun manual kepada komponen hardware tersebut.

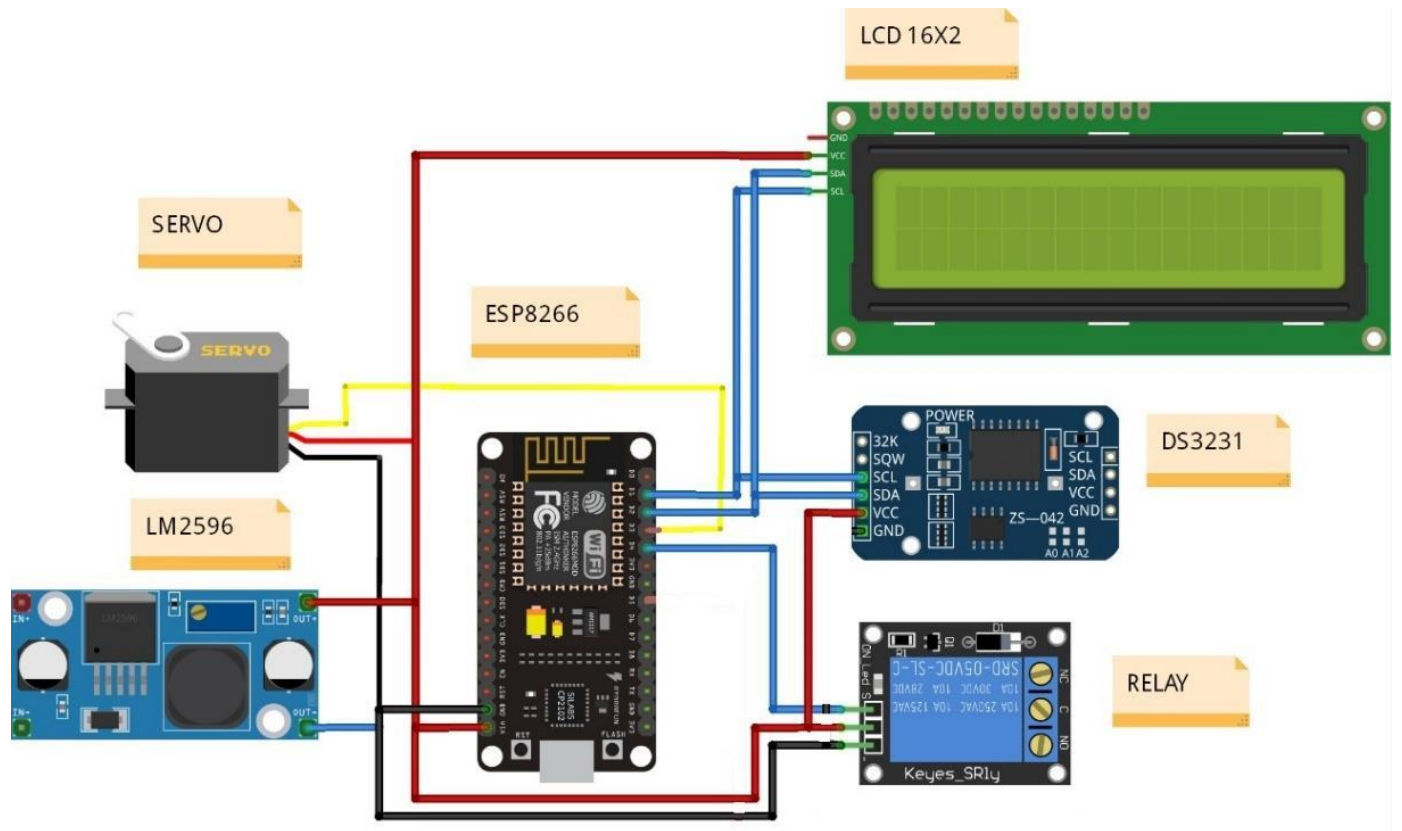

Gambar 4. Rangkaian alat Pakan Otomatis

Pengujian mikrokontroller NodeMCU ESP8266 dengan aplikasi Blynk untuk mengetahui apakah aplikasi Blynk sudah terintegrasi dengan alat pakan otomatis. Pada saat 
ditekan tombol on maka servo pada alat pakan ikan cupang langsung bergerak sebesar $135^{\circ}$, $90^{\circ}, 45^{\circ}$ dengan tujuan untuk memberi makan ikan dalam waktu bersamaan.

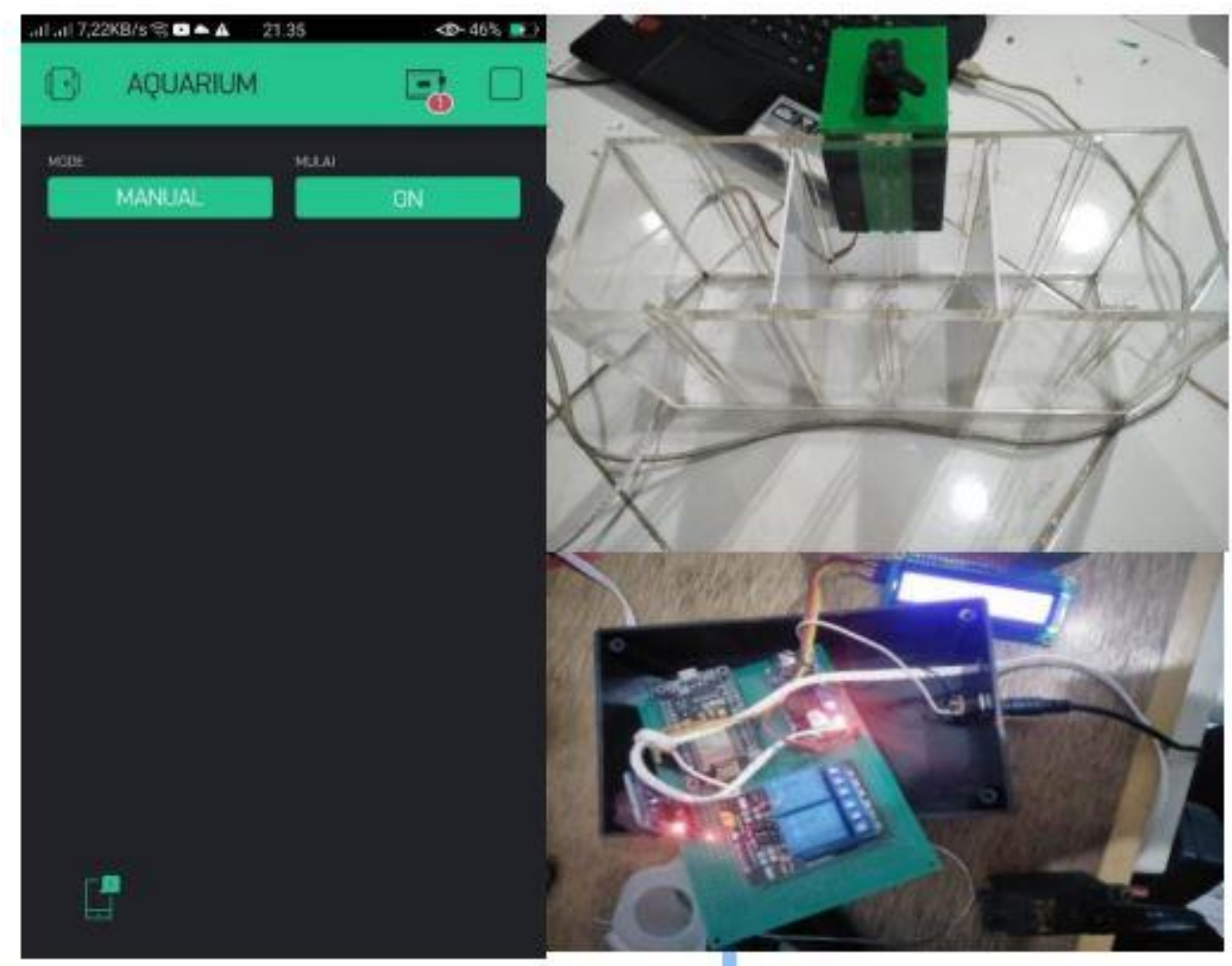

Gambar 5. Pengujian Alat Pakan Ikan Cupang

Pada gambar 5 menjelaskan aplikasi blynk yang mampu memberi perintah kepada servo agar bergerak ketika diberi perintah ON.

\section{KESIMPULAN DAN REKOMENDASI}

\section{Kesimpulan}

Berdasarkan dari pembahasan yang telah dilaksanakan terhadap pembuatan alat pakan ikan cupang otomatis maka dapat diambil kesimpulan bahwa perancangan alat pakan ikan cupang ini dapat memberikan gambaran kepada para peternak atau pemelihara ikan cupang bahwa alat inilah yang nantinya akan dijadikan sebagai acuan dalam memberi makan ikan cupang sehari-hari. Dengan adanya prototipe alat pemberi pakan ikan cupang otomatis ini yang hanya dapat memberi makan 3 ekor ikan cupang saja, kedepannya dapat dikembangkan sehingga dapat memberi makan lebih banyak ikan cupang.

Alat pakan otomatis untuk ikan cupang ini diterapkan pada toko ikan cupang King Rosetail untuk memberi makan ikan cupang secara otomatis tanpa harus mempekerjakan staff secara berlebih hanya untuk memberi makan ikan cupang. Hanya perlu menggunakan smartphone dan install aplikasi Blynk, maka pemilik toko ikan cupang tersebut atau 
pemelihara ikan cupang langsung dapat memberi makan ikan cupang dari jarak jauh menggunakan smartphone nya.

\section{Rekomendasi}

Adapun rekomendasi yang disampaikan yaitu untuk kedepannya dalam dunia budidaya ikan cupang harus sudah berkolaborasi dengan ilmu teknologi, terutama dalam bidang Internet Of Things (IoT). Hal ini dilakukan agar ada modernisasi dalam pengembangan teknologi di pembudidayaan ikan cupang dan ikan hias lainnya. Pemeliharaan alat pakan ikan cupang sangat mudah dilakukan. Namun tetap harus dilakukan dengan pengecekan minimal 1 bulan sekali untuk memeriksa terjadinya error pada mikrokontroler ataupun hardware lainnya.

\section{REFERENSI}

Andriawan, Ferry. "Penjadwal Pakan Koi Otomatis Pada Kolam Menggunakan RTCDS3231" (2018).

Andriawan, Ferry. "Penjadwal Pakan Koi Otomatis Pada Kolam Menggunakan RTCDS3231" (2018).

Darmanto, Rendi. Rancang Bangun Step Down DC To DC Converter Monolithic IC LM 2596. Diss. Universitas Muhammadiyah Palembang, 2019.

Sisinni, Emiliano, et al. "Industrial internet of things: Challenges, opportunities, and directions." IEEE Transactions on Industrial Informatics 14.11 (2018): 4724-4734.

Sugiyono (2016: 407), Research and Development (R\&D)

Samsugi, Selamet, Zainabun Mardiyansyah, and Andi Nurkholis. "Sistem Pengontrol Irigasi Otomatis Menggunakan Mikrokontroler Arduino UNO." Jurnal Teknologi dan Sistem Tertanam 1.1 (2020): 17-22.

Sutabri, T., Widodo, Y. B., Sibuea, S., Rajiani, I., \& Hasan, Y. (2019). Tankmate Design For Settings Filter, Temperature, and Light on Aquascape. Journal of Southwest Jiaotong University .

Widodo, Y. B., Ichsan, A. M., \& Sutabri, T. (2020). Perancangan Sistem Smart Home Dengan Konsep Internet Of Things Hybrid Berbasis Protokol Message Queuing Telemetry Transport. Jurnal Teknologi Informatika dan Komputer, 124.

Wicaksono, Mochamad Fajar. "Implementasi Modul Wifi Nodemcu Esp8266 Untuk Smart Home." Komputika: Jurnal Sistem Komputer 6.1 (2017). 